\title{
プトレマイオス朝エジプト研究の新動向
}

—J. Manning, Land and Power in Ptolemaic Egypt の到達点

\section{A Review of Recent Research on the Ptolemaic State}

\author{
高 橋 亮 介 \\ TAKAHASHI Ryosuke
}

I. はじめに

プトレマイオス朝エジプトについて, 強大な権力をもつ王がその支配地たるエジプト を, 複雑ではあるが効率的な官僚機構と中央統制計画経済をもって収奪したという理解 が長らくなされてきた。ところが強力な中央集権国家という伝統的なプトレマイオス朝 像は, 1960年代以降, 批判にさらされ, 見直しが進んでいる。例えば, 生産の㛜格な管理 と考えられてきた「歳入法」は, 徵税プロセスの強化・統制を意図したものであったこ と,「耕作日程表」は, 中央からの耕作の指令書ではなく, 地方からの収穫の見積もりで あったことが指摘されている。またオイコノモス oikovónosという地方官僚に農業・牧 畜・手工業の監督を命じた中央からの指令書は, 常に実践されるものではなく儀礼的な 意味合いを持っていたことが指摘されている（Turner 1984 ; Walbank 1991/2 ; 森谷 1997 ; Shipley 2000, 192-234; Manning 2003, 21-24)。これらギリシア語史料の読み直し を通してプトレマイオス朝像を修正する動向の代表としてサミュエル A. E. Samuel を 挙げることが出来る (Samuel 1983；1989；1993. cf. Walbank 1991/2, 100)。

他方, 1990年代に入り顕著になったもう一つの新しい研究動向はデモティック (民衆文 字）史料の活用であり，ギリシア語史料からは知ることの出来ないプトレマイオス朝社 会像を明らかにしつつある (Walbank 1996, 112-113)。昨年出版されたマニングの Land and Power in Ptolemaic Egypt: The Structure of Land Tenure (Manning 2003) は, プト レマイオス朝を論じな単行本としては最新のものであるが, 上エジプトからのデモティ ック史料の校訂，およびそこでの土地保有権を研究してきたエジプト学者がプトレマイ

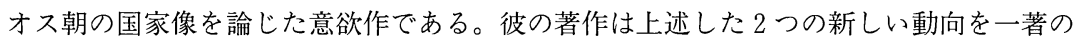
中に体現したものであり, 近年のプトレマイオス朝研究の一つの到達点と言えよう。本 稿では, このマニングの議論をまとめ, 伝統学説への批判を紹介した後 (I ), サミュエ

* 東京大学大学院総合文化研究科博士課程

Ph. D. Student, Graduate School of Arts and Sciences, The University of Tokyo 
ルの説との比較を通して新しい研究の中での異同を見ることによって (II)，プトレマイ オス朝研究の最新の動向を明らかにしたい。

\section{II. 伝統学説批判}

マニングの最新刊は，そのタイトルが示す通りプトレマイオス朝期において富の源泉 である土地がどのように管理・統制されたか，また中央と地方の経済の関係を考察する ことにより伝統的な国家像の修正を試みている。同時にプトレマイオス朝における土地 保有に関する史料の見取り図を描き，デモティック史料がプトレマイオス朝の発展と経 済構造の複雑さの理解にいかなる貢献をなしうるかを示す，という目的も掲げられてお り，情報量は多く内容は多岐に渡る。従ってここで彼の議論の全てを紹介することは出 来ないが, プトレマイオス朝の国家像に関するマニングの議論を要約する。

ファイユーム地方からの豊富なギリシア語史料は，中央の統制の効いたいわゆる「王 室経済」と効率的な官僚制の存在を強調する国家像を作り上げてきた。しかしギリシア 人入植者が多いため中央の統制も効きやすく，急速に変化の生じたファイユームはむし ろ特殊であり，人口・耕地面積の点でもエジプトの典型とは見なせない。一方，上エジ プト，テーバイ地方には，個人または家族が小規模の土地を保有し，相続・移譲をする 伝統的な土地保有制度が残り，神殿が地方経済の拠点として大きな力を持っていた。し かしこれまでテーバイ地方のデモティック史料はファイユームの特殊性を明らかにして きたものの，ギリシア語史料と結びつけられて論じられることは少なかった。そこでマ ニングは，2つの言語による史料と 2 つの地域を視野に入れ，土地所有体制の観点から プトレマイオス朝エジプトという国家を論じることを試みる。

マニングの議論は, エジプトの地理・歴史への理解と, 最近マンによって唱えられた 歴史上の社会の理論的考察 (マン 2003) の応用を前提としている。エジプトはナイル河 に沿った細長い耕作地が氾濫という自然現象によって潅溉されるため, 地域によっても 年によっても農業生産の状況は異なり, 中央の命令による画一的かつ直接的な農業経営 は不可能であった。そのため地方レベルでの現実に即した測量, 耕作, 徵税の実践が求 められており，エジプトの支配者は常に地方エリートとの協働を必要とした。またすで にペルシア帝国の支配期から地方勢力に頼りつつも中央集権を進める試みは始まってお りプトレマイオス朝は以前の社会経済制度を踏襲した。

他方, ある社会はイデオロギー, 経済, 軍事, 政治という 4 つの力の相互関係として 理解されるべきとのマンの主張を受けて，マニングはこれら 4 つの力は重なり合う部分 があるとしながらも，王権イデオロギーやギリシア・マケドニア人の軍事力に引きずら れることなく，プトレマイオス朝がどのような経済組織を持っていたのかを理解する必 
要があるとする。

以上の前提に基づき，上エジプトを中心に土地保有体制やその他の経済制度に対する 統制を論じることにより，プトレマイオス朝を中央の統制の強い国家と捉えること，お よび土地私有化の度合いで中央の統制の強弱を測ることが批判されるのである。

マニングによれば，土地に対する国家の統制は先行研究が見なしてきたよりも強くは なく, テーバイにおいて土地私有は一貫して存続し, 地方における私的な経済活動にも 統制が加えられることはなかった。国家の統制は，土地を巡る契約の登録と課税，徵税 請負，国営穀物庫や銀行を通しての徵税といった制度を地方経済に導入するという形を 取り，余剩生産物と税の徵収の合理化が進められた。そしてこれらの制度を監督したの が地方官僚であったが, 彼らは行政機構の中に組み込まれた地方エリートであった。他 方, 土地所有権こそ損なわれることはなかったが, 官僚制度の発展に伴い, 神殿の徵税 機構としての役割は行政機構によって奪われていく。こうしてみるとプトレマイオス朝 は，生産にまで徹底した管理が及ぶといった伝統的な意味での中央集権国家ではなかっ た。確かに歳入増加のシステムを発展させ，ギリシア語を用いる官僚制を行き渡らせる ことで，これまでにない中央化に成功したのであるが，このシステムはこれまで考えら れてきたように初期の王たちによって短期間に作り上げられたものではなく，地方との 緊張・交渉・協㗢を経て徐々に発展したのものであった。また地方官僚の協力を必要と するこのシステムは，国家歳入の増加と同時に彼らに力を与えるものであった。

他方, 既存の土地保有体制を維持しつつ歳入増加のシステムの確立を進めたプトレマ イオス朝にとって, 土地の私有の度合いは国家の衰退の指標とはならない。むしろ支配 の維持・強化のために土地の賦与を通じて, 軍人・官僚を国家に奉仕させることが必要 であった。ただしこれは彼ら地方エリートの経済力を増すものであり，中央の力が弱く なったときに彼らの自立を容易にするものであった。

\section{III. サミュエル説との比較}

マニングの描くプトレマイオス朝像は, 土地制度と地方経済を温存し, 地方との協働 により歳入の最大化を図ったというものであり，中央による全面的な経済統制を否定す るものである。また地域経済とそれを統制する官僚制の強化は，中央の政治力の衰退と 無関係に発展し，地方勢力の台頭に拍車をかけたのであった。彼のプトレマイオス朝像 が, 土地所有者としての王の力が強く,「王室経済」こそがプトレマイオス朝の経済であ ったとする伝統学説と大きく異なっているのだが，冒頭でも述べたように近年の研究状 況は全体として旧来の国家像の批判・修正へと向かっており，彼の説もその流れに位置 する。ところが伝統学説を批判する研究の中にも差違が存在する。プトレマイオス朝国 
家像の修正主義者の代表とも言えるサミュエル（Samuel 1983；1989；1993）とマニング とを比較したとき，両者の間には，類似点と同時に相違点も見いだすことができる。両 者の異同は，サミュエルがギリシア史・ヘレニズム史の観点からプトレマイオス朝を捉 えようとしているのに対し，マニングがエジプト史の観点からプトレマイオス朝を理解 しようとするという姿勢の違いを示している。以下，最近の研究にも言及しながら両者 を比較していく。

\section{1. 類似点}

マニングの主張の大枠はすでにサミュエルらによってなされている。マニングは中央 の介入は生産にまで及ぶことができないというエジプト農業の本質をプトレマイオス朝 期についても論じ，上エジプトの土地保有体制から中央の統制の弱さを実証した。しか しこれまでの修正論者たちが，中央集権国家像の解体を論じてきたことを思えば，マニ ングは重要な論拠を加えたとはいえ，これまでの方向性に従っていると言える。その場 合，マニングの研究は彼らの議論を補完する意味を持つ。両者の類似点として，中央と 地方の経済的な繫がりの弱さの指摘と衰退史観への批判の 2 点を取り上げよう。

国家の関心が，土地あるいは生産そのものに及んでいなかったことは指摘されて久し い。サミュエルは，ウェーバー M. Weber やロストフツェフ M. Rostovtzeff が近代的な 経済観念を古代史研究に持ち込み，経済的発展や成長を古代人が自明の目標と見なして いたことを批判する。プトレマイオス朝は生産増加のために, 人々を組織し, 新技術の 導入を図ったというロストフツェフの主張に対し，中央の生産管理を示すとされてきた ギリシア語史料の読み直しを受けて，プトレマイオス朝は生産そのものではなく，歳入 の最大化を目指し，徵税の効率化を図ったと論じた（Samuel 1983, 1-10, 39-61)。

また土地私有の問題についてもサミュエルは，ギリシア語史料に現れる土地区分は， 私有地と国有地の別ではなく，土地の耕作・納税における責任の所在を示しているとの 指摘をしている。すなわち王領が耕作者と役人との間の仲介者の不在を示すのに対し， 神殿領や高官への賦与地 $\delta \omega \rho \varepsilon \alpha i$ は彼らが仲介者であることを示し，また兵士に与えられ る入植地 $\kappa \lambda \tilde{\eta} \rho \circ$ は，彼らに富をもたらしたのだが，同時に国家に対する義務も伴ってい たのであった（Samuel 1989, 58-59）。他方，マニングは王がエジプトに伝統的な徵税権 と放棄された農地を割り当てる権利を持っていたと主張しており，両者の見解に差違は あるものの，農地と王との関係が間接的なものであったと見なす点において似たような 理解を示している。

中央による地方への統制が強く，生産をも管理すると見る限り，王の弱体化・中央の 政治的混乱が, 地方の農業生産の停滞を引き起こし, エジプト全体が衰退していくとい 
う理解が生まれる。しかし，この理解の前提となる中央と地方の関係を従来主張されて きたほど強固なものではなかったと見なされたとき，新しい見方が可能になる。第 2 の 類似点はこの衰退史観に対する修正である。

マニングは, 最初の 3 人の王がプトレマイオス朝の繁栄を築き, その後は衰退してい くというプトレマイオス朝像を, 政治史を扱った叙述史料から作られたものとして，工 ジプトの社会経済史の理解にもあてはめることを批判する。実際には地方の騒擾や王室 の内紛によって中央が地方から歳入を得る回路を失ったとしても, 地方の農業生産・経 済活動は中央とは関係なく存続するのである。経済統制の組織化・合理化は中央の歳入 増だけでなく地方官僚自身にも利益をもたらすものとして地方からの要求もあり進めら れたが, 中央は地方官僚の存在なしに地方を支配できないので彼らを排除できず, 国家 の代理人として地方官僚は力を蓄えていったのである。こうして中央が政治的混乱を迎 えたときに，地方は容易に自立することができた (Manning 2003, 230-236)。プトレマイ オス朝期にはギリシア語を用いる官僚機構が全土に行き渡り発展しつつも, 中央の力が 強い時期には地方が束ねられ, 弱体化の時期には地方勢力が自立するという王朝時代以 来のエジプト政治史のパターンがプトレマイオス朝期にも見て取れる (cf. 屋形 1998 ; Shaw 2000)。従って王権の衰退はエジプトの全体的衰退とは一致しないのである。

他方, サミュエルも王と行政機構の関係についての考察から王の弱体化とエジプトの 衰退が一致しないことを主張している(Samuel 1989, 51-65 ; Samuel 1993)。複雑な行政 機構は, 中央の合理的な計画に基づいたものではなく，官僚となった移住ギリシア人の 私益をも追求すべく形成され，官僚自身の利益を増大させようとする動きとそれに対す る王の介入を通して変化していく。初期の王たちは廷臣と肥大化しつつある官僚を用い て政治を行ったが, その後, 廷臣たちが中央政治を担うようになる。彼らは地方官僚に 対し名誉的な廷臣称号の賦与を通じて官僚との協力体制を作り，またエジプト人神官層 とも妥協を図った。これは地方勢力の自立を加速させたであろう。そして地方行政は王 室の内紛期においても相争う王の統治年を並記しながら王の存在とは無関係に機能し続 けていたのである。サミュエルは王の行政における役割を部分的なもの，あるいは王は 行政の外に位置すると見なす。王が出す特赦状 $\varphi$ L $\alpha \dot{\alpha} v \theta \lambda \omega \pi \alpha$ は混乱の回収を図った行政文 書ではなく，民の安寧を気遣う王というイデオロギーの発現であった。マニングはエジ プトにおける地方行政の性格から, またサミュエルは官僚の自己利益追求から地方と中 央との距離を論じているが, 王権の衰退にも関わらず, 地方行政・経済が機能し続ける という両者の見解には類似点が見られる。 


\section{2. 相違点}

マニングとサミュエルには相違点もある。それらは相互に関連しているがエジプト史 の観点, 行政の合理性, 地域差の重視，エジプト人の役割の 4 点に分けられよう。

マニングはエジプト史の観点からプトレマイオス朝を捉えようとし，アレクサンドロ ス到来以前も視野に入れる (Manning 2003，8-9，39-43）。時折独立しながらもリビア， ヌビア，アッシリア，ペルシア，そしてギリシア・マケドニア人と支配者が替わった紀 元前一千年紀をエジプト史における外国支配の一千年期として捉える。エジプトはその 前半に, 地中海世界を形成する部分となり, 強力な海軍を備え, 穀物を輸出する。また ギリシア人移民の増加，貨幣の使用の開始，エジプト全体を統合する行政言語であるデ モティックの使用の開始, 司法制度の整備といったプトレマイオス朝の支配を理解する 上で重要な要素が姿を見せ始めることが指摘され，ペルシアの支配が地方エリートに依 存していたことも指摘される。これら具体的な記述は，サミュエルもプトレマイオス朝 がサイス朝以前の遺制を可能な限り活用したであろうことを認めながらも，プトレマイ オス朝以前の影響を考察するにはエジプト学者との学問的交流がないことを嘆いている のと対照的である (Samuel 1989, 53)。またサミュエルは，前述した地方行政の中央から の自立の動きをエジプト史の観点から捉えることをしていない。

他方，プトレマイオス朝とローマ属州エジプトとの関係について両者の見解には著し い違いがある。マニングは農業生産・調査・登録に関係する官僚制度の発達，神殿から の経済力の奪取, 行政言語としてのデモティックの衰退という現象についてプトレマイ オス朝はローマ帝国を先駆けていたと評価するのに対して (Manning 2003, 236-237), サ ミュエルは，プトレマイオス・ローマ期という括りで理解されてきたエジプト史を否定 し両時代の違いを強調したルイス（Lewis 1970）を受けて次のように述べる。「プトレマ イオス朝エジプトをローマ属州への発展の段階に位置づけることはもはやできない。プ トレマイオス朝の行政機構は, 先進的なへレニズムの影響によるオリエントの官僚制の 合理化の結果とは見なせないのである」(Samuel 1989, 83-84)。プトレマイオス期とロー マ期エジプトに大きな違いがあることに今日異を唱えるものはいないが，マニングはそ の違いをローマ人の支配に帰すのではなくエジプト自体の歴史的発展という観点から理 (8) 解しようとしている。マニングはサミュエルに比して前後の時代を視野に入れ緩やかな 変化の時代としてプトレマイオス朝期を見ている。

またプトレマイオス朝とローマ期との関係，とりわけ行政機構をめぐる両者の見解の 違いは, 第 2 の相違点, 行政の合理性の再評価として見ることができよう。サミュエル は行政機構の形成・変遷が，合理的な中央の計画によるものではなく，場当たり的な部 分修正と私益を追求しようとする官僚自身によっていたと見なす（Samuel 1993，175- 
180)。しかし中央のマスタープランの有無, あるいはその実践のみが合理性の存在を示す ものではないだろう。例えばバグナルは, エジプト行政の複雑さと変遷の背後には, 歳入 増加の合理化と統制強化という目的に限定して変更が加えられ, 既存の地域差を無視し た統一性の追求は意図されていなかったという原則があったと指摘している（Bagnall 1976, 9-10)。このような遺制を残しつつ行われた部分修正にもサミュエルはネガティブ な判断を下すが，地域差への柔軟な対応にこそ合理性が現れていると見ることもできよ う。サミュエルは官僚機構が非合理的なものであり，中央がその意志を貫徹させようと することが困難であったと見ているが，マニングは古い遺制の残るテーバイにおいても プトレマイオス朝の影響力が及び，効率的な歳入増加システムが徐々に構築されたこと を示した (Manning 2003, 129-181)。マニングの理解は, 特に明示されないがサミュエル よりもバクナルの理解に近い。共に「強力な中央集権国家」を批判しながら中央の力の 及び方, 行政機構の合理化についての評価には相違が見られる。

この違いはマニングが地域差およびプトレマイオス朝におけるエジプト人の存在を重 視していることに基づいている。サミュエルらがファイュームの特殊性を強調し, ギリ シア語史料の読み直しから中央統制体制の批判を行ったのに対し，マニングはデモティ ック史料を用いてテーバイの状況を具体的に描いた (Manning 2003, 65-98, 182-225)。そ してそこに土地私有という伝統的な体制には手をつけず，徵税機構の精緻化によって歳 入を増加させたシステムを見いだしたのである。ファイユームとの比較を行いながら上 エジプトの状況を仔細に描くことで，プトレマイオス朝がエジプト内の地域差に対して どのように支配を確立していったかを実証した意義は大きい。

エジプト人の存在はプトレマイオス朝の中でどのような位置をしめていたのか。これ はプトレマイオス朝エジプトを考える際に誰もが思い浮かべる問題であるが, ここにも 両者の見解の違いが見られる。サミュエルが私益を追求する官僚と述べるとき, 移住し たギリシア人たちが含意され（Samuel 1993, 178)，権限が強く広域に責任を負う高位官 僚が想定されている。他方マニングは，国家の代理人としての地方エリートという言葉 を用いて役人を表現し，より地域的な官僚を想定している (Manning 2003, 130-133)。2 人とも個々の官職について詳しく述べているわけではないが，彼らは行政機構における 異なるレベルの官僚について語っており，両者の理解は矛盾するものではない。しかし ここにプトレマイオス朝という国家の構成要素として何を重視するのかについて両者の 視点の違いが特徵的に現れている。私益を追求しようとするギリシア人高位官僚と「外 国支配の一千年期」を通じて身につけた柔軟さをもって支配者に対応し, 伝統的な地方 行政を担う現地のエリートたち。そのどちらも存在したであろうが, とりわけ後者の存 在は軽視されるべきはない。プトレマイオス朝初期においてすら州 vouósレベルの行政 
職のみならず, 廷臣としても将軍としても重んじられていたエジプト人の存在が最近明 らかにされた (Lloyd 2003)。ギリシア人によるエジプト人の支配という構図は摇らぎつ つある。

\section{IV. 結びにかえて}

プトレマイオス朝エジプトの理解を巡って, 強力な中央集権国家像を修正する最近の 動向，さらに後者の中での差違を見てきた。マニングは土地保有とそれに対する国家の 統制という観点からプトレマイオス朝エジプトの国家像を描き，自らの設定した課題に 対して十分な成功を収めたと言える。サミュエルの主張と比較しても，デモティック史 料の活用，エジプト史の理解に支えられた国家像はよりバランスの取れたものとなって いる。しかしマニングの業績はプトレマイオス朝エジプトという国家の全体像を提示す るものではない。農業以外の産業, 海外領を含んだ地中海帝国としての位置づけや軍事 史，東方・南方との貿易などいくつもの側面からの考察を経て，プトレマイオス朝エジ プトの国家像が再構築されなければならない。

にもかかわらず彼の業績はプトレマイオス朝研究史上, 伝統学説の修正よりも大きな 転換点に位置している。マニングの新しさは, 彼自身の学問的背景と環境, すなわち工 ジプト学の学位を持ちデモティック文書の校訂をしてきたこと,そして古典古代学科(ス タンフォード大学) に属し, 研究・教育に携わっていることに負っているはずだが, 大 きな研究動向の中で理解されるである。それを示すためプトレマイオス朝エジプト研究 全般を進展させる 2 つ要因を指摘して稿を閉じたい。

まず史料の絶対量の増加である。パピルス文書はエジプト学および西洋古代史研究に おける史料としてはすでに公刊された史料の多さもさることながら,膨大な量の校訂(再 校訂）・公刊が待たれている点で特異な史料である。必然的にパピルス史料を用いたあ らゆる研究は「予備的な」研究にならざるを得ず，新史料の公刊によって旧来の研究の 見直しが常に求められる研究分野である（Bagnall 1995, 109-117）。またパピルス文書だ けでなく考古学の成果も顧慮されねばならないのは言うまでもない。

もう1つはあらゆる歴史研究にあてはまることだが歴史家の生きた時代・社会が，史 料から何かを読みとり，何らかの社会像を再構成する作業に及ぼす影響である。ギリシ ア人によるオリエント支配が高度な文明を生んだと論じたドロイゼン J. G. Droysen, へ レニズム世界を都市ブルジョワジーに支えられた経済圈として捉えたロストフツェフら は当時の帝国主義の思想と無縁ではいられなかった。そのことを指摘したサミュエルは, 自らのプトレマイオス朝像が彼自身の同時代への理解や経験からいくぶん主観的に作ら れたことを自覚していた。彼のネガティブな官僚制理解には，自らの国家や専門家への 
不信が影を落としている。また文化融合の場としてへレニズム世界を捉えることに異を 唱えギリシア文化と現地文化の断絶を強調したプレオ（Preaux 1978）を支持するとき， 彼女の主張がフランドル文化の存続・復興が唱えられた時期のベルギーでなされたこと を指摘する。そして彼自身もまた多文化主義政策をとるカナダに生きた研究者であった (Samuel 1989, 1-12)。しかしそのサミュエルもあくまでギリシア史の視点からプトレ マイオス朝を捉えようとする姿勢を貫いた。

1990年代以降顕著になったデモティック史料を使った研究の増加, エジプト人の視点・ エジプト学の観点からプトレマイオス朝を捉えようとする研究動向をポストコロニアル 的視座の導入と評することが出来る (Rowlandson 2003, 263)。それは個別研究から知る ことが出来るが (例えば Johnson 1992; Verhoogt \& Vleeming 1998 に収められた諸論 文)，デモティック学者の手によるプトレマイオス朝の概説書 (Chauveau 2000) やデモ ティック文書についての入門書（Depauw 1997）も著されている。この動向の中でギリ シア・マケドニア人対エジプト人，支配者対被支配者という二項対立関係でプトレマイ オス朝を把握することは放棄されつつある。マニングは, 中央と地方の緊張・協働関係 をプトレマイオス朝理解の根幹に据え, エジプト人を受動的な被支配者と見なすことを 否定した。またプトレマイオス朝研究に安易に近代植民地支配のアナロジーを持ち込む ことを批判する意見 (Bagnall 1997) や,「世界システム論」を援用し，エジプト本土（コ 一ラ）をプトレマイオス帝国の「周辺」として経済的な収奪の対象として捉えることの 有効性を否定する見解（Shipley 1993）も現れてきている。ギリシア・デモティック両語 からなる家族文書の分析は，ギリシア文化とエジプト文化は融合したのか断絶していた のか, プトレマイオス朝エジプトに生きた人々は「ギリシア化」したのか「エジプト化」 したのかという問いをも止揚する。融合文化は生まれなかったものの,プトレマイオス 朝の支配は 1 人の人間が同時にエジプト文化の行動様式もギリシア文化のそれも身につ け，生活の様々な局面で時にはエジプト人として時にはギリシア人として振る舞うこと の出来たバイカルチャー社会を作り上げた（Clarysse 1985; Rowlandson 2003)。共にプ トレマイオス朝エジプトの国家論に挑み，いくつかの結論を共有しながらもサミュエル とマニングの立つ位置は大きく異なっている。プトレマイオス朝期, そしてローマ・ビ ザンツ期のエジプト研究は長らく古典古代学・西洋史の領域であったが, エジプト学・ 東洋学との稔りある対話をする時期を迎えたと言える。

注

(1) P. Rev. パピルス史料の略号は Oates et al. 2001 に従う。

(2) P. Yale 36. 
( 3 ) P. Teb. 703.

（4）サミュエルの合理性批判は, 経済人類学者ポランニーK. Polany や古代史家フィ ンリー（Finley 1999）に賛同してなされたものであった。彼によれば近代的な合理化 を阻害したのは，ギリシア人の公私の概念の不在である（Samuel 1983; Samuel 1993， 178 ; cf. Rostovtzeff 1941，269-271)。なお近年のフィンリー批判については Morris 1999 ; Archibald et al. 2001 を参照。

（5）ロストフツェフも，王たちがエジプトの伝統的制度を維持しつつも，土地からの 歳入を得るシステムを改良したことを指摘している (Rostovtzeff 1941, 291)。

(6) ロストフツェフ (Rostovtzeff 1941, 267-332), ターナー (Turner 1984, 133-159) はともにプトレマイオス 2 世を行政機構をもっとも効果的に機能させた人物とみなし, その後を混乱と衰退の時期と見る。ただし両者の彼に対する評価は異なり，ターナー は 2 世をエジプトを破産させた人物と見なし称賛の対象にすらならない。最近，生産 の向上と結びつかない歳入増加の試みは被支配者に多くの負担を強いるものであった が，プトレマイオス朝はその試みおいて全面的な成功したわけでも，過酷な圧制をし たわけでもないというバランスの取れた見解が示された（Shipley 2000, 225-234）。後 述するようにマニングもプトレマイオス朝期を通じてローマ期に繫がる緩やかな行政 の発展を想定している。

（7）ただし王の存在を行政から排除するこの見解には批判がある（Walbank 1991/2, 110)。

（8）地方行政が他の属州と同様に富裕な都市住民によって担われるようになったこと がローマ期の大きな特徴である (Bowman \& Rathbone 1992)。しかし都市住民と村落 住民の違いは，ローマ期において法的に区別されるようになるが，社会的にはすでに プトレマイオス期に生じていたとの指摘がある（Rowlandson 2003）。マニングの地方 エリートの伸張という主張はこれらの説と矛盾しない。またローマのエジプト支配と いう経験が他のローマ属州統治に影響を及ぼした可能性も指摘されている (Rathbone 1993)。

（9）官僚機構の非合理性を主張するサミュエルだが，すでに見たように歳入増加が試 みられたことを指摘している。

（10）この問題を掘り下げるためには官僚制度の実証研究が不可欠である。個々の官職 とその担い手, 官職間の相互関係の変遷を考察した後, 改めて合理化の問題に立ち返 る必要があるだろう。なお行政機構の研究には邦語の優れた研究があり(藤森 1996), 我が国において進展が期待できる分野である。

（11）さらにパピルス文書をそれが発見された物理的な文脈と照らし合わせて解釈する ことも重要である (cf. van Minnen 1994)。

（12）ただし彼はデモティック史料の刊行が有力エジプト人について新たな知見をもた らすであろうことを正しく予期していた（Samuel 1989, 48)。 


\section{参照文献}

Archibald, Z. H. et al. (eds.) 2001: Hellenistic Economies, London/New York.

Bagnall, R.S. 1976: The Administration of the Ptolemaic Possessions outside Egypt, Leiden.

Bagnall, R. S. 1995: Reading Papyri, Writing Ancient History, London/New York.

Bagnall, R. S. 1997: "Decolonizing Ptolemaic Egypt," in P. Cartledge et al. (eds.), Hellenistic Constructs, Berkeley, 225-241.

Bowman, A. K. \& D. Rathbone 1992: "Cities and Administration in Roman Egypt," Journal of Roman Studies 82, 107-127.

Chauveau, M. 2000: Egypt in the Age of Cleopatra, trans. by D. Lorton, Ithaca/London (Original French edition, L'Égypte au temps de Clépatre, Paris, 1997).

Clarysse, W. 1985: "Greeks and Egyptians in the Ptolemaic Army and Administration," Aegyptus 65, 57-66.

Davies, J.K. 1984²: "Cultural, Social and Economic Features of the Hellenistic World," in F. W. Walbank et al. (eds.), Cambridge Ancient History, VII-1, Cambridge, 257-320.

Depauw, M. 1997: A Companion to Demotic Studies, Brussels.

Finley, M. 1999: Ancient Economy, updated 2nd ed., Berkeley.

Johnson, J. H. (ed.) 1992: Life in a Multi-cultural Society: Egypt from Cambyses to Constantine and Beyond, Chicago.

Lewis, N. 1970: “"Greco-Roman Egypt”: Fact or Fiction?,” in D. H. Samuel (ed.), Proceedings of the Twelfth International Congress of Papyrology, Toronto, 3-14.

Lloyd, A. B. 2003: "The Egyptian Elite in the Early Ptolemaic Period: Some Hieroglyphic Evidence," in D. Ogden (ed.), The Hellenistic World: New Perspectives, London/Swansea, 117-136.

Manning, J. 2003: Land and Power in Ptolemaic Egypt: The Structure of Land Tenure, Cambridge.

Morris, I. 1999: "Forward," in Finley 1999, ix-xxxvi.

Oates, J. F., et al. $2001^{5}$ : Checklist of Edition of Greek, Latin, Demotic and Coptic Papyri, Ostraca and Tablets, Bulletin of the American Society of Papyrologists, Supplement 9.

Préux, C. 1978: Le monde hellénistique: La Grèce et l'Orient de la mort d'Alexandre à la conquête romaine de la Grèce (323-146 av. J.-C.), 2 vols., Paris.

Rathbone, D. W. 1993: "Egypt, Augustus and Roman Taxation," Cahires du Centre G. Glotz 4, 81-112.

Rostovtzeff, M. 1941: Social and Economic History of the Hellenistic World, 3 vols., Oxford. 
Rowlandson, J. 2003: "Town and Country in Ptolemaic Egypt," in A. Erskine (ed.), A Companion to the Hellenistic World, Oxfrod, 249-263.

Samuel, A. E. 1983: From Athens to Alexandria: Hellenism and Social Goals in Ptolemaic Egypt, Leuven.

Samuel, A. E. 1989: The Shifting Sands of History: Interpretations of Ptolemaic Egypt, Lanham.

Samuel, A. E. 1993: "The Ptolemies and Ideology of Kingship," in P. Green (ed.), Hellenistic History and Culture, Berkley/Los Angeles, 169-192.

Shipley, G. 1993: "Distance, Development, Decline?: World-Systems Analysis and the "Hellenistic" World," in P. Bilde et al. (eds.), Centre and Periphery in the Hellenistic World, Aarhus, 271-284.

Shipley, G. 2000: Greek World after Alexander, London/New York.

Show, I. (ed.) 2000: The Oxford History of Ancient Egypt, Oxford.

Turner, E. G. 1984²: "Ptolemaic Egypt," in F. W. Walbank et al. (eds.), Cambridge Ancient History, VII-1, Cambridge, 118-174.

van Minnen, P. 1994: "House to House Enquiries: An Interdiciplinary Approach to Roman Karanis," Zeitschrift für Papyrologie und Epigraphik 100, 227-251.

Verhoogt, A. \& S. P. Vleeming (eds.) 1998: The Two Faces of Graeco-Roman Egypt: Greek and Demotic and Greek-Demotic Texts and Studies Presented to P. W. Pestman, Leiden.

Walbank, F. W. 1991/2: “The Hellenistic World: New Trends and Directions," Scripta Classica Israelica 11, 90-113.

Walbank, F. W. 1996: "Recent Work in Hellenistic History," Dialogos 3, 111-119.

藤森誠 1996 :「プトレマイオス朝期の下及び中エジプトにおけるノモス・ストラテーゴ ス職：プトレマイオス朝の地方行政機構の一考察」『西洋史研究』新輯 $25 ， 46-73$ 。 マン, M. 2002 ：『ソーシャルパワー：社会的な「力」の歴史』森本醇, 君塚直隆 (訳), NTT 出版。

森谷公俊 1997 ：「ヘレニズム諸国家」伊藤貞夫, 本村凌二 (編)『西洋古代史研究入門』 東京大学出版会, 120-124。

屋形禎亮 1998：「古代エジプト」『岩波講座世界歴史 2 オリエント世界：－７世紀』岩 波書店, 31-60。 